\title{
Patrimonio paleontológico: un legado olvidado
}

\author{
Cristina Sousa Macías | gestora cultural \\ URL de la contribución <www.iaph.es/revistaph/index.php/revistaph/article/view/4147>
}

\begin{abstract}
"El mundo se mueve a un ritmo tan acelerado que la mayoría de las personas irrumpió en el siglo XXI olvidando sus orígenes. Debiera ser al revés. Deberíamos valorizar nuestras raíces y nuestra cultura, y utilizarlas como cimientos para construir nuestro futuro".

Recomendaciones de estudiantes en el Foro Juvenil del Patrimonio Mundial, Pekín (China)
\end{abstract}

Tratar el patrimonio paleontológico es tratar de entender si realmente es patrimonio. Normalmente se tiende a confundir esta disciplina con la arqueológica y es que, aunque en ocasiones compartan el mismo método de trabajo, son ramas diferentes entre sí y con áreas de conocimientos desiguales, es por ello por lo que se llega al planteamiento de si el "patrimonio" paleontológico necesita de un marco legal propio y específico.

Pese a todos los bienes paleontológicos que podemos referenciar, no se establece un marco legal con cobertura amplia para hacer de este patrimonio un enclave único de protección y conservación. Es más, ¿es considerada la paleontología patrimonio cultural?

Aunque la respuesta depende de los bienes paleontológicos a los que se haga referencia, me atrevería a decir que no, la paleontología está regida bajo la ley de patrimonio histórico español de 1985 , donde se incluye los "bienes de interés paleontológicos" junto a los bienes de interés histórico, por lo tanto la paleontología carece de un marco legal propio y específico. Y, por supuesto, debe de tenerlo.

Esta rama es una contribución más en nuestro patrimonio y por lo tanto sus valores son fundamentales para nuestra sociedad, tanto científicos, sociales como económicos. Es un patrimonio olvidado, en ocasiones comparado y poco valorado; razón por la que expertos en la materia demandan más protección, conservación, difusión y financiación, para seguir con sus labores de investigación, cruciales para una mejora en nuestro patrimonio, que debe ser enormemente cuidado, conocido y conservado por todos los ciudadanos. El patrimonio siempre debe de estar en constante desarrollo e investigación, ya que aporta una riqueza muy necesaria para el progreso de nuestro país. Por ello se debe contemplar leyes que amparen y salvaguarden nuestro extenso patrimonio, y la paleontología no puede ser menos.

Esclarecemos, pues, que la protección de dicho patrimonio debe ser una clave fundamental para su desarrollo, por ello necesita de más cobertura legal, no solo para su salvaguarda sino para evitar el expolio o el vandalismo, dado que como legado histórico, éste es símbolo de un alto valor y atractivo. Si no existe una protección legal, o la protección está enfocada a varios yacimientos, no se podrá evitar estos acontecimientos y tendremos un patrimonio abandonado, expoliado y robado. Por estas razones se necesitan normas que puedan interpretarse de modo que concilien las facilidades a la investigación con la conservación y difusión del patrimonio paleontológico, puesto que será la única forma de evitar exponer nuestro patrimonio y protegerlo adecuadamente.

Esta falta de protección afecta de lleno a los paleontólogos. El papel de un paleontólogo es imprescindible a la hora de valorar, catalogar, inventariar y responder ante un proyecto de paleontología. Y aunque es así y lo sabemos, desafortunadamente son menos investigadores los que llegan a hacer posible uno de estos proyectos; la principal causa, la falta de financiación e investigación en el ámbito paleontológico. En este contexto, la Sociedad Española de Paleontología sigue sin jugar el papel que debería corresponderle como interlocutor o institución consultiva de las administraciones. Estas 
instituciones estatales deben de proteger y preservar la seguridad y salvaguarda de los yacimientos, donde los paleontólogos investigarán para una futura inversión en la mejora del patrimonio paleontológico. Cabe destacar que un paleontólogo estudia fósiles para desarrollar el conocimiento de las antiguas formas de vida y su medio ambiente, ligado al patrimonio por el alto contenido histórico de los bienes que son trabajados por estos profesionales.

Para dichos profesionales, que normalmente son geólogos con licenciaturas en paleontología, resulta vital una enseñanza en cuanto a patrimonio, ya que su trabajo es imprescindible a la hora de ejecutar la planificación de un trabajo de campo. Por ello desde hace décadas existen numerosas publicaciones que unen la relación geológica con la patrimonial estableciendo el estudio del patrimonio geológico español, el cual surge por una necesidad de divulgación social en los entornos educativos e incluso como uso turístico.

Cabe destacar que, bajo este criterio, el patrimonio paleontológico ha recibido una especial atención en las distintas comunidades autónomas, como se refleja en la Comisión de Patrimonio Geológico de la Sociedad Española de Paleontología formada en 1991 para la conservación y protección del patrimonio paleontológico español en dichas comunidades.

Por otro lado, las nuevas tecnologías permiten innovar y facilitar el trabajo que conlleva la investigación y elaboración del patrimonio paleontológico. Esto supone un avance en cuanto a inventariado, registro y catalogación de las piezas, prestando su búsqueda y medidas de conservación y protegiendo la obra adecuadamente dado los informes y fichas técnicas.

También el avance tecnológico aporta difusión mediante redes sociales del patrimonio, lo que ayuda a la concienciación ciudadana de la importancia sobre el patrimonio, lo que genera a su vez que la sociedad se involucre y conozca las obras que lo integran. Acto muy importante para la protección y salvaguarda del mismo.

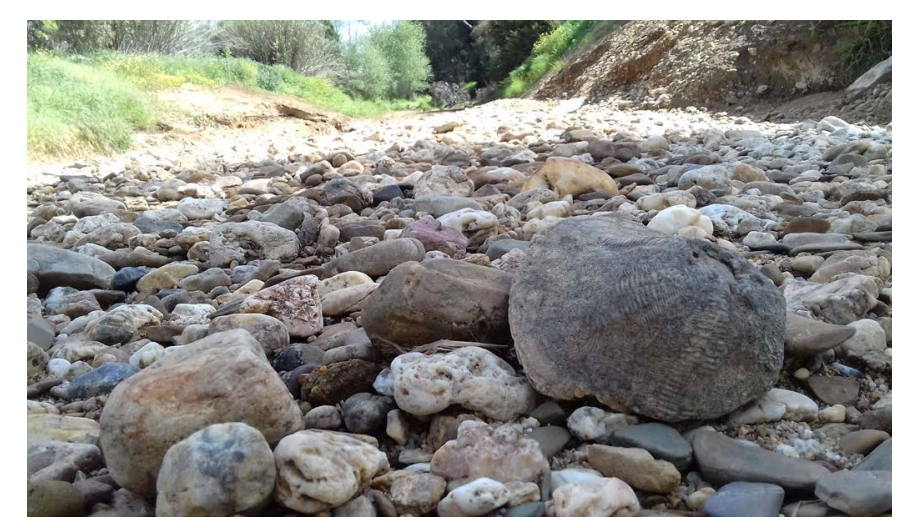

Equinodermo de la familia de los Clypeaster. Rivera de Nicoba, afluente del río Tinto, que atraviesa los municipios de Gibraleón y Trigueros, en la provincia de Huelva | foto José Ramírez Cuadri

Finalmente, observamos que pese a todos los organismos surgidos para garantizar la existencia de tan nombrado patrimonio, aun escasean las medidas para su mejora y futura conservación. Es un patrimonio que se contiene estancado y no en constante evolución como merece. Por ello se debe difundir, proteger y conservar, pero sobre todo educar, educar colectivamente para la salvaguarda de tan valioso bien, que no solo supone un medio social y cultural, sino que es un recurso económico que genera riqueza en la sociedad.

Educar sobre patrimonio es avalar nuestro legado histórico. Mantener el patrimonio paleontológico es mantener las costumbres, tradiciones, avances culturales y una evolución constante. Cuidar lo que tenemos en común es proteger una diversidad cultural aprendida y generada. Se necesita más protección, más investigación y más difusión, para hacer de nuestra historia un legado socialmente protegido.

\section{BIBLIOGRAFÍA}

- ALCALÁ, L. (1999) Reflexiones acerca de la protección del patrimonio paleontológico en España. Coloquios de Paleontología, 50, 1999, pp. 45-51 